\title{
Influences of different space allowance on reproductive performances in buffalo
}

\author{
Angela Salzano ${ }^{1}$, Maria Stefania Spagnuolo ${ }^{2}$, Pietro Lombardi ${ }^{1}$, Domenico Vecchio ${ }^{3,6}$, Antonio Limone ${ }^{4}$, \\ Sergio Bolletti Censi ${ }^{5}$, Anna Balestrieri ${ }^{4}$, Alessandra Pelagalli ${ }^{1}$, Gianluca Neglia ${ }^{1}$ \\ ${ }^{1}$ Department of Veterinary Medicine and Animal Production, Federico II University, Naples, Italy. \\ ${ }^{2}$ Institute for the Animal Production System in the Mediterranean Environment (ISPAAM), National Research Council (CNR), \\ Naples, Italy. \\ ${ }^{3}$ Istituto Zooprofilattico Sperimentale del Mezzogiorno, National Reference Centre for Hygiene and Technologies of Water \\ Buffalo Farming and Productions, Fuorni (Salerno), Italy. \\ ${ }^{4}$ Istituto Zooprofilattico Sperimentale del Mezzogiorno, Naples, Italy \\ ${ }^{5}$ Cosvitec Ricerca and Formazione, Naples, Italy.
}

\begin{abstract}
The aim of this study was to evaluate the effect of two different conditions of space allowance on reproductive performance and oxidative parameters, biochemical and hormonal profiles in buffalo. The trial was carried out on one hundred pluriparous buffaloes divided into two different groups. Buffaloes in group HDG (high density group - $\mathrm{n}=50$ ) were maintained in open yards that allowed $10 \mathrm{~m}^{2} /$ head while those in group LDG (low density group - $\mathrm{n}=50$ ) were maintained in $22 \mathrm{~m}^{2} /$ head. After 60 days, 45 buffaloes in each group underwent synchronization of ovulation by Ovsynch and were artificially inseminated to assess the reproductive efficiency. On the day of AI blood samples were collected to evaluate oxidative stress, hormonal and metabolic profile. Furthermore, on the same day, blood, saliva and hair samples were collected to assess cortisol levels. Simultaneously, five buffaloes/group, were synchronized but not inseminated and on the day of the hypothetical timed artificial insemination (TAI), follicular fluid was recovered by OPU and blood samples were collected from each animal to evaluate the redox status on both plasma and follicular fluid. Conception rate on day 70 post-AI was similar between the two groups ( $57.5 v s .62 .5 \%$, in LDG and HDG, respectively). No significant differences were found on redox status, metabolic and hormonal profile and cortisol levels between the groups. In conclusion, on the conditions of this experiment it was observed that the space allowance of $10 \mathrm{~m}^{2} /$ head did not affect reproductive efficiency in buffalo cows.
\end{abstract}

Keywords: buffalo, oxidative stress, reproductive performances, space allowance.

\section{Introduction}

Nowadays, the intensification of buffalo farming techniques led to a reduction of space allowance, compared with dairy cattle standards that are recognized in $10 \mathrm{~m}^{2} /$ head (Andrews and Poole, 2004). Several studies performed in buffalo analyzed the influence of space reduction $\left(10 \mathrm{~m}^{2} /\right.$ head $v s .36$ $\mathrm{m}^{2} /$ head) on some behavioural indicators in different categories (De Rosa et al., 2009). Due to the importance of water availability for the species, the effect of a pool or potholes has been assessed on reproduction behavior on buffalo cows (Di Palo et al., 2001) and on production of buffalo heifers (De Rosa et al., 2007). Furthermore, a positive correlation was observed between space allowance $\left(22 \mathrm{~m}^{2} / \mathrm{head}\right)$ and milk production (Zicarelli et al., 2005).

Space reduction may be responsible of stress and physiological homeostasis alteration, stimulating numerous pathways leading to increased levels of reactive oxygen species (ROS). The damaging action of ROS, if not counteracted or prevented by antioxidant defenses, causes cell death, tissue oxidative stress and organ ageing or failure (Halliwell and Gutteridge, 1999). Ascorbate (Asc), $\alpha$-tocopherol (Toc) and retinol (Ret) are able to scavenge ROS and prevent oxidative damage, in the hydrophilic and lipophilic compartment and their concentration in plasma could be used as marker of oxidative stress (Spagnuolo et al., 2011). The concentration of protein-bound carbonyls (PC) and nitro-tyrosine (N-Tyr) in blood plasma, is also a reliable method to evaluate the extent of oxidative protein damage (Beal, 2002; Dalle-Donne et al., 2003) as N-Tyr and PC are considered markers of ROS-mediated protein oxidation (Berlett and Stadtman, 1997).

Measuring hypothalamic-pituitary-adrenocortical (HPA) axis activity can be considered another approach to study stress and welfare in farm animals (Mormède $e t$ al., 2007). Recently, the assessment of chronic stress (Möstl et al., 2002; Negrão et al, 2004; Ferranti et al., 2011) is performed by measuring glucocorticoid hormones (cortisol or corticosterone) in blood, saliva, urine and feces. Moreover, hematological parameters have been reported to provide valuable information on the immune and physiological status of the animal, distinguishing health and stress status (Doyle, 2006).

There is strong suggestion that space allowance affects reproductive performance in sow (Hemsworth $e t$ al., 2013; Johnston and $\mathrm{Li}, 2013)$ and hens (Garner et al., 2012). Tuner et al. (2005) reported that female pigs are quite resistant to the effects of acute or repeated acute stress on reproduction, whereas the prolonged stress may alter reproductive performances. It cannot be ruled out that the stress status due to space allowance in buffalo may also affect reproductive efficiency.

Therefore, the aim of this study were to assess: a) the influence of space allowance on reproductive performance and b) the oxidative parameters, biochemical and hormonal profiles. 


\section{Materials and Methods}

Animals, space allowance and experimental design

The experiment was carried out of the breeding season (spring and summer period) in a commercial farm in Southern Italy (latitude $40.5^{\circ}-41.5^{\circ} \mathrm{N}$ and longitude $\left.13.5^{\circ}-15.5^{\circ} \mathrm{W}\right)$. The influence of space allowance treatment was assessed using 100 lactating buffaloes (110 \pm 12 days in milk) of $129 \mathrm{~kg}$ metabolic weight (MW). In the previous lactation their average milk production over 270 days was greater than 2700 $\mathrm{kg}$. The buffaloes were milked twice daily and were fed a total mixed ration (TMR) based on corn silage, wheat straw, soybean meal, barley meal, corn meal, wheat bran, beet pulp, hydrogenate vegetable fat, and vitamin and mineral supplement. The diet was characterized by $50-55 \%$ forage and $45-50 \%$ concentrate and contained 0.90 milk forage units (MFUkg of dry matter (DM) and $15 \%$ of crude protein (CP)DM in a group pen situation. Water was provided ad libitum throughout the course of the study. Before the start of the trial, the animals were maintained in open yards that allowed 10 $\mathrm{m}^{2} /$ head. Cows were randomly divided into two homogeneous groups (50 buffaloes) housed in open yards that allowed $10 \mathrm{~m}^{2} /$ head (high density group HDG) and $22 \mathrm{~m}^{2} /$ head (low density group - LDG). Milk yield, at the beginning of the study, was $10.3 \pm 1.3$ $\mathrm{kg}$ /day (group HD) and 10.0 $\pm 1.2 \mathrm{~kg} /$ day (group LD).

Data collection started after an adaptation period of 60 days. Forty-five animals per group were utilized to assess the reproductive performance and to evaluate oxidative stress, hormonal and metabolic profile, while five buffaloes per group were utilized to assess the redox status in both blood and follicular fluid. Finally, individual milk yield was also recorded throughout the trial.

\section{Synchronization of ovulation, AI, and pregnancy}

Sixty days after the beginning of the trial, the buffaloes underwent synchronization treatment. The synchronization protocol used, Ovsynch with timed AI, was similar to that developed for cattle (Pursley et al., 1995) and previously applied in buffaloes (Neglia et al., 2003b, 2008; Rossi et al., 2014). Artificial inseminations were performed by the same operator and each buffalo was inseminated once $20 \mathrm{~h}$ after the second injection of $\mathrm{GnRH}$ agonist. Because of the relatively low intensity of estrous behavior in buffaloes (Ohashi, 1994), animals underwent ultrasound examination immediately before AI using a portable SonoAce PICO Ultrasound unit (Medison, Seoul, South Korea) equipped with a $10-\mathrm{MHz}$ linear transducer adapted for transrectal examination in large animals to assess estrous status (follicle $>1.0 \mathrm{~cm}$ ). Furthermore, transrectal palpation was carried out to evaluate uterine tone with the presence or absence of mucous vaginal discharge. Twenty-five days after AI, buffaloes underwent transrectal ultrasonography to assess embryonic development by visualizing the presence of the embryo and a proper heartbeat rate. Ultrasonography was carried out by the same experienced operator.
Conception was assessed on day 25, 45 and 70 after AI by ultrasonography. Buffaloes with embryonic development on day 25 , but not pregnant on day 45 , were considered to have undergone late embryonic mortality (LEM). Buffaloes with embryonic development on day 45 , but not pregnant on day 70 , were considered to have undergone foetal mortality (FM).

\section{Progesterone}

Function of the CL was determined by measuring circulating concentrations of P4 by RIA (Nieswender, 1973; Skaggs et al., 1986) in blood samples collected from the jugular vein into heparinized tubes on days 10, 20 and 25 after AI. Samples were centrifuged at $800 \mathrm{X} g$ for $15 \mathrm{~min}$ and the plasma stored at $-20^{\circ} \mathrm{C}$ until required for $\mathrm{P} 4$ assay which was carried out at the same time for all samples. Concentrations of $\mathrm{P} 4>1.5 \mathrm{ng} / \mathrm{ml}$ were considered to be indicative of the presence of an active CL (Zicarelli et al., 1997). The minimum detectable amount of progesterone was $2.1 \pm$ $0.1 \mathrm{pg}$ and the intra- and interassay coefficients of variation were 6.2 and $11.8 \%$, respectively.

\section{Antioxidant analysis}

At moment of AI, blood samples were collected from the jugular vein into $10 \mathrm{ml}$ lithiumheparinized tubes to analyze liposoluble (retinol and $\alpha$ tocopherol) and idrophylic (ascorbate) antioxidants as well as markers of protein oxidation such as nitrotyrosine (N-Tyr) and protein-bound carbonyls (PC). Ascorbate, retinol and $\alpha$-tocopherol blood levels were measured according to Spagnuolo et al. (2003). Briefly, plasma samples for determination of Asc concentration were prepared and analysed by HPLC using an anion exchange column (Nucleosil $100 \mathrm{NH}_{2}, 5 \mu \mathrm{m}, 250 \times 4.6$ $\mathrm{mm}$ i.d.; Macherey-Nagel). Chromatography was carried out at a flow rate of $0.8 \mathrm{ml} / \mathrm{min}$, with 50 $\mathrm{mMNaH}_{2} \mathrm{PO}_{4}: \mathrm{CH}_{3} \mathrm{CN}(35: 65, \mathrm{v}: \mathrm{v})$ as mobile phase. A $\mathrm{UV}$-spectrophotometer was used to detect the elution of Asc, which was identified by retention time and absorbance spectrum. Absorbance at $254 \mathrm{~nm}$, and calibration curves $\left(\mathrm{r}^{2}>0.9997\right)$ obtained by injecting different amounts $(n=12)$ of standard were used for quantitative analysis. Samples for determination of Ret and Toc were prepared and analysed by HPLC. A reverse phase $\mathrm{C} 18$ column was chosen for chromatography (Nova-PAK C18, $4 \mu \mathrm{m}, 125 \times 2 \mathrm{~mm}$ i.d.; Macherey-Nagel). The analysis was carried out with isopropanol: methanol: water (46.25:46.25:7.5, $\mathrm{v}: \mathrm{v}: \mathrm{v})$ as mobile phase, at $0.2 \mathrm{ml} / \mathrm{min}$, using a programmable fluorescence spectrometer for detection. In particular, Ret was detected by setting $\lambda \mathrm{EX}=325 \mathrm{~nm}$ and $\lambda \mathrm{EM}=465 \mathrm{~nm}$ from 0 to $5 \mathrm{~min}$, while Toc was detected by $\lambda \mathrm{EX}=295 \mathrm{~nm}$ and $\lambda \mathrm{EM}=335 \mathrm{~nm}$ from 5 to $8 \mathrm{~min}$. Calibration curves $\left(\mathrm{r}^{2} \geq 0.9998\right)$, obtained by injecting different amounts $(n=12)$ of standard, were used for quantitative analysis. LPO concentration was measured by a colorimetric quantitative assay, using the lipid hydroperoxide assay kit of Cayman Chemical according to the manufacturer's instructions.

$\mathrm{N}-\mathrm{Tyr}$ levels in blood plasma were determined 
by ELISA as previously reported by Spagnuolo et al. (2001). Plasma samples were diluted (1:100, 1:500, $1: 1000,1: 3000,1: 6000$, and 1:10000) with coating buffer $\left(7 \mathrm{mMNa}_{2} \mathrm{CO}_{3}, 17 \mathrm{mMNaHCO}_{3}, 1,5 \mathrm{mMNaN}_{3}, \mathrm{pH}\right.$ $=9.6$ ) and incubated in the wells of a microtitre plate overnight at $4^{\circ} \mathrm{C}$. Standard curves were obtained with serial dilutions of nitrated BSA. N-Tyr was detected by incubation with rabbit anti-N-Tyr antibody (1:500 dilution in $130 \mathrm{mM}-\mathrm{NaCl}, 20 \mathrm{mMTrisHCl}, 0,05 \%$ Tween $20, \mathrm{pH}=7.3$, supplemented with $0,25 \% \mathrm{BSA} ; 1 \mathrm{~h}$, $37^{\circ} \mathrm{C}$ ) followed by goat anti rabbit IgG-horseradish peroxidase linked (GAR-HRP) diluted 1:2000 as the primary antibody. Colour development was monitored at $492 \mathrm{~nm}$, as previously described (Spagnuolo et al. 2003). Data were reported as nmol of N-Tyr per mg of protein.

Protein-bound carbonyls (PC) in blood plasma were titrated by ELISA according to Buss et al. (1997). Triple assay were made for PC and N-Tyr samples, while double assay were made for $\alpha$-tocopherol, retinol and ascorbate samples.

\section{Metabolic profile and complete blood count}

Blood samples were collected on day of AI from the jugular vein in vacutainer tubes. The tubes were centrifuged at $3000 \mathrm{~g}$ for $15 \mathrm{~min}$. The recovered serum was stored at $-18^{\circ} \mathrm{C}$ until analysis for metabolic profile. Glucose was measured on plasma by means of a colorimetric method. Blood chemistry parameters (urea, creatinine, total cholesterol, HDL cholesterol, triglycerides, ALT, AST, GGT and total proteins) were measured on serum using kits by Spinreact (Santa Coloma, Spain) by enzymatic colorimetric or kinetic methods according to manufacturer instructions. Red blood cells, white blood cells, platelets, hemoglobin, hematocrit, mean corpuscular volume, mean corpuscular hemoglobin, mean corpuscular hemoglobin concentration, neutrophils, lymphocytes, eosinophils, and monocytes were also analysed in heparinized blood samples using an automatic blood analyzer (ADVIA 120 Siemens, Munich, Germany).

\section{Cortisol determination and $\beta$-endorfin}

On the day of AI, blood, saliva and hair samples were collected to analyze cortisol levels. Blood samples were taken from the jugular vein into $10 \mathrm{ml}$ normal tubes, saliva samples were recovered using Salivette ${ }^{\circledR}$ buffer and hair samples in anagen phase were collected with razor. Hair samples were taken from withers with anaverage length of the hair of $1-3 \mathrm{~cm}$ and an average weight of $250 \mathrm{mg}$. Simultaneously, further blood samples were collected from the jugular vein into $10 \mathrm{ml}$ lithium-heparinized tubes to assess $\beta$-endorfin concentration. Blood samples were centrifuged at $800 \mathrm{X}$ $g$ for $10 \mathrm{~min}$ and serum was stored at $-20^{\circ} \mathrm{C}$ until ELISA analysis (DBC Diagnostic Biochem Canada Inc.). Salivette ${ }^{\circledR}$ buffers were centrifuged and then stored at $70^{\circ} \mathrm{C}$ until ELISA analysis (DBC Diagnostic Biochem Canada Inc.). Hair samples were washed into an isopropanol solution, dried for 5 days, tritured and extracted with methanol for $18 \mathrm{~h}$. Nitrogen evaporator at $37^{\circ} \mathrm{C}$ was used to remove the hair liquid phase and the concentration of cortisol was assessed by ELISA kit (DBC Diagnostic Biochem Canada Inc.). $\beta$-endorfin determination was performed in plasma samples already centrifuged at $800 \mathrm{X} \mathrm{g}$ for $15 \mathrm{~min}$ and stored at $-70^{\circ} \mathrm{C}$ by ELISA kit (EK-022-06, Phoenix Pharmaceuticals, Inc. Berlingame, USA).

\section{Redox status in blood and follicular fluid}

Five buffaloes in each group were selected to assess the redox status also in the follicular fluid of the dominant follicle. In particular, the animals underwent the same synchronization protocol described above. After $28 \mathrm{~h}$ from the last $\mathrm{GnRH}$ injection the follicular fluid of the dominant follicle was recovered by Ovum pick-up (OPU), according to Neglia et al. (2003a). Ovum pick up setting consisted of a portable ultrasound unit (SonoAce PICO, Medison, Seoul, South Korea) with a convex $4 \mathrm{MHz}-9 \mathrm{MHz}$ probe (mod.CD4-9/10EDN) and a metal guide, to fit on the top 18 gauge needles, allocated in a properly designed vaginal guide (WTA Ltda., Cravinhos, $\mathrm{SP}$, Brazil). A vacuum pressure of $40 \mathrm{~mm}-\mathrm{Hg}$ was constantly maintained by using a suction unit (K-MAR5100, Cook IVF Co.Australia). The $15 \mathrm{ml}$ Falcon tubes (Becton \& Dickinson Co., Lincoln Park, NJ, USA) for fluid collection were constantly maintained at $37^{\circ} \mathrm{C}$.

On the same day of OPU, blood samples were collected from the jugular vein into $10 \mathrm{ml}$ lithiumheparinized tubes. Samples were centrifuged at 500X $g$ for $15 \mathrm{~min}$ at $4{ }^{\circ} \mathrm{C}$. Liposoluble and idrophylic antioxidants and marker of protein oxidation were analyzed on follicular fluid and on blood plasma as described above (see paragraph 2.4).

\section{Statistical analysis}

Differences between experimental groups in milk yield, antioxidant parameters, steroid hormones (progesterone and oestradiol), metabolic profile, blood count parameters, cortisol and $\beta$-endorfin levels were tested by ANOVA (SAS GLM Procedure mix model; SAS $\backslash S T A T .2000$. User's Guide, Version 6:03). The redox status in blood and follicular fluid in two experimental groups were tested by Student's t test. Finally, differences in pregnancy rates, embryonic and foetal mortality between the groups were analyzed by Chi-square test.

\section{Results}

During the post-adaptation period a mean temperature of $27.3^{\circ} \mathrm{C}$ was recorded (minimum $18.9^{\circ} \mathrm{C}$ and maximum $31.8^{\circ} \mathrm{C}$ ). Relative humidity was $59.2 \%$ in average. Of the 90 buffaloes synchronized, 10 (11.1\%; belonged to both groups) did not have a follicle $>1.0 \mathrm{~cm}$ and a tonic uterus and hence were excluded from the trial. Conception rate assessed on 25, 45 and 70 days post AI was similar between the two groups and no differences were also present for LEM and FM (Table 1).

Progesterone blood levels recorded in pregnant buffaloes on day 10 post AI were higher $(\mathrm{P}<0.05)$ compared to both not pregnant counterparts and animals that underwent LEM (Table 2). These differences were higher $(\mathrm{P}<0.01)$ on days 20 and 25 post AI (Table 2$)$. The treatment did not affect progesterone levels in both groups. 
Table 1. Conception rate on day $25(\mathrm{P} 25), 45(\mathrm{P} 45)$ and $70(\mathrm{P} 70)$ post-insemination in buffaloes maintained in different space allowance conditions. The incidences of late embryonic mortality (LEM) and foetal mortality (FM) are also reported.

\begin{tabular}{lccc}
\hline & Low density & High density & P value \\
\hline P25 (n) & $72.5 \%(29 / 40)$ & $72.5 \%(29 / 40)$ & 1 \\
P45 (n) & $57.5 \%(23 / 40)$ & $67.5 \%(27 / 40)$ & 0.36 \\
P70 (n) & $57.5 \%(23 / 40)$ & $62.5 \%(25 / 40)$ & 0.65 \\
LEM (n) & $20.7 \%(6 / 29)$ & $6.9 \%(2 / 29)$ & 0.13 \\
FM (n) & $0.0 \%(0 / 23)$ & $7.4 \%(2 / 27)$ & 0.18 \\
\hline
\end{tabular}

Table 2. Blood progesterone (P4) level 10, 20 and 25 days post $\mathrm{AI}$ in animals pregnant (P), not pregnant (NP) and in those underwent late embryonic mortality (LEM), independently of the group.

\begin{tabular}{lcccc}
\hline & $\mathrm{P}(\mathrm{n}=50)$ & $\mathrm{NP}(\mathrm{n}=22)$ & LEM $(\mathrm{n}=8)$ & P value \\
\hline P4 $10(\mathrm{ng} / \mathrm{ml})$ & $3.0 \pm 0.2^{\mathrm{a}}$ & $2.4 \pm 0.4^{\mathrm{b}}$ & $2.1 \pm 0.7^{\mathrm{b}}$ & 0.049 \\
P4 20 (ng/ml) & $3.7 \pm 0.2^{\mathrm{A}}$ & $1.8 \pm 0.5^{\mathrm{B}}$ & $2.0 \pm 0.8^{\mathrm{B}}$ & 0.003 \\
P4 25 $(\mathrm{ng} / \mathrm{ml})$ & $4.1 \pm 0.2^{\mathrm{A}}$ & $1.1 \pm 0.3^{\mathrm{B}}$ & $2.2 \pm 0.8^{\mathrm{B}}$ & 0.001 \\
\hline
\end{tabular}

Values with different superscripts within rows are significantly different: ${ }^{\mathrm{a}, \mathrm{b}} \mathrm{P}<0.05 ;{ }^{\mathrm{A}, \mathrm{B}} \mathrm{P}<0.01$.

Interestingly, no differences were present in the redox status between pregnant, not pregnant and buffaloes underwent LEM. Ascorbate, retinol and $\alpha$ tocopherol blood levels, as well as N-Tyr e PC blood levels were similar between the two groups (Table 3).
No differences were also observed between the groups in terms of cortisol (in serum, saliva and hair), and $\beta$-endorfin blood levels (Table 4). Furthermore, the metabolic profile and the complete blood count carried out on the day of AI did not show significant differences between groups (Table 5 and 6 ).

Table 3. Redox titration in blood plasma of buffaloes maintained in different space allowance conditions.

\begin{tabular}{lccc}
\hline Antioxidants & $\begin{array}{c}\text { Low density } \\
(\mathrm{n}=40)\end{array}$ & $\begin{array}{c}\text { High density } \\
(\mathrm{n}=40)\end{array}$ & P value \\
\hline Retinol $(\mu \mathrm{g} / \mathrm{ml})$ & $0.5 \pm 0.0$ & $0.5 \pm 0.0$ & 0.15 \\
$\alpha$-tocopherol $(\mu \mathrm{g} / \mathrm{ml})$ & $1.7 \pm 0.1$ & $1.8 \pm 0.1$ & 0.52 \\
Ascorbate $(\mu \mathrm{m})$ & $5.3 \pm 0.3$ & $5.3 \pm 0.2$ & 0.95 \\
Protein-bound carbonyls $(\mathrm{nmoles} / \mathrm{mgP})$ & $7.4 \pm 0.7$ & $8.0 \pm 0.8$ & 0.60 \\
Nitrotyrosine $(\mathrm{nmoles} / \mathrm{mgP})$ & $1.3 \pm 0.1$ & $1.4 \pm 0.1$ & 0.51 \\
\hline
\end{tabular}

Table 4. Cortisol concentration in blood serum, saliva and hair, and blood $\beta$-endorfin concentration of buffaloes maintained in different space allowance conditions.

\begin{tabular}{lrrr}
\hline Parameter & Low density & \multicolumn{1}{c}{ High density } & P value \\
& $(\mathrm{n}=40)$ & $(\mathrm{n}=40)$ & \\
\hline Cortisol in blood serum $(\mathrm{ng} / \mathrm{ml})$ & $20.2 \pm 0.6$ & $20.8 \pm 0.7$ & 0.52 \\
Cortisol in saliva $(\mathrm{ng} / \mathrm{ml})$ & $2.9 \pm 0.1$ & $3.1 \pm 0.1$ & 0.82 \\
Cortisol in hair $(\mathrm{pg} / \mathrm{mg})$ & $57.3 \pm 1.9$ & $50.5 \pm 1.7$ & 0.06 \\
$\beta$-endorfin $(\mathrm{ng} / \mathrm{ml})$ & $0.3 \pm 0.0$ & $0.3 \pm 0.0$ & 0.49 \\
\hline
\end{tabular}

Table 5. Metabolic profile of buffaloes maintained in different space allowance conditions the day of AI .

\begin{tabular}{lccc}
\hline & \multicolumn{3}{c}{ Day of AI } \\
\cline { 2 - 4 } & $\begin{array}{c}\text { Control group } \\
(\mathrm{n}=40)\end{array}$ & $\begin{array}{c}\text { Treated group } \\
(\mathrm{n}=40)\end{array}$ & P value \\
\hline Gluc $(\mathrm{mg} / \mathrm{dl})$ & $39.5 \pm 1.9$ & $37.6 \pm 1.9$ & 0.48 \\
LDH (U/l) & $558.8 \pm 29.2$ & $595.8 \pm 33.9$ & 0.41 \\
Ggt (U/l) & $15.2 \pm 0.6$ & $14.7 \pm 0.9$ & 0.65 \\
Ast (U/l) & $80.9 \pm 1.8$ & $75.3 \pm 3.9$ & 0.18 \\
Alt (U/l) & $26.5 \pm 1.5$ & $25.7 \pm 1.1$ & 0.69 \\
Alp (U/l) & $137.3 \pm 9.6$ & $120.0 \pm 6.7$ & 0.95 \\
Ck (U/l) & $35.7 \pm 1.4$ & $33.2 \pm 1.7$ & 0.95 \\
Urea (mg/dl) & $38.9 \pm 1.9$ & $37.1 \pm 1.5$ & 0.46 \\
Tri (mg/dl) & $5.8 \pm 0.3$ & $5.6 \pm 0.4$ & 0.74 \\
Col (mg/dl) & $105.2 \pm 6.5$ & $110.8 \pm 6.5$ & 0.55 \\
Pt (mg/ml) & $70.9 \pm 1.6$ & $68.9 \pm 1.6$ & 0.37 \\
Crea (mg/dl) & $5.1 \pm 1.0$ & $2.3 \pm 0.0$ & 0.06 \\
\hline
\end{tabular}


Table 6. Complete blood count of buffaloes maintained in different space allowance conditions the day of AI.

\begin{tabular}{lccc}
\hline & \multicolumn{2}{c}{ Day of AI } \\
\cline { 2 - 4 } & $\begin{array}{c}\text { Control group } \\
(\mathrm{n}=40)\end{array}$ & $\begin{array}{c}\text { Treated group } \\
(\mathrm{n}=40)\end{array}$ & P value \\
\hline RBC $\left(10^{6} / \mu \mathrm{l}\right)$ & $5.6 \pm 0.3$ & $5.2 \pm 0.2$ & 0.28 \\
WBC $\left(10^{3} / \mu \mathrm{l}\right)$ & $6.7 \pm 0.4$ & $7.3 \pm 0.5$ & 0.33 \\
PLT $\left(10^{3} / \mathrm{mm}^{3}\right)$ & $354.9 \pm 13.5$ & $355.56 \pm 17.7$ & 0.97 \\
HB $(\mathrm{g} / \mathrm{dl})$ & $14.2 \pm 0.2$ & $14.5 \pm 0.3$ & 0.37 \\
HT $(\%)$ & $39.7 \pm 1.1$ & $39.8 \pm 1.1$ & 0.94 \\
MCV $\left(10^{2} / \mathrm{ml}\right)$ & $55.5 \pm 1.2$ & $51.4 \pm 0.9$ & 0.06 \\
MCH $(\mathrm{pg})$ & $12.7 \pm 0.2$ & $12.9 \pm 0.2$ & 0.20 \\
MCHC $(\mathrm{g} / \mathrm{dl})$ & $36.6 \pm 0.6$ & $35.4 \pm 0.7$ & 0.09 \\
NEUTRO $\left(10^{3} / \mu \mathrm{l}\right)$ & $2.8 \pm 0.1$ & $2.9 \pm 0.1$ & 0.94 \\
LINF $\left(10^{3} / \mu \mathrm{l}\right)$ & $5.8 \pm 0.1$ & $5.0 \pm 0.2$ & 0.06 \\
EOS $\left(10^{3} / \mu \mathrm{Ll}\right.$ & $1.5 \pm 0.1$ & $1.5 \pm 0.1$ & 0.95 \\
MONO $\left(10^{3} / \mu \mathrm{l}\right)$ & $0.4 \pm 0.0$ & $0.2 \pm 0.0$ & 0.08 \\
\hline
\end{tabular}

No effect of space availability was also observed on plasma and follicular fluid redox indexes on the day of estrus (Table 7). Finally, milk yield/day/head recorded between the two Groups during the experimental period was similar $(9.3 \pm 0.9$ vs. $9.7 \pm 0.9$ in $\mathrm{LDG}$ and $\mathrm{HDG}$, respectively; Fig. 1).

Table 7. Redox status evaluated in the follicular fluid and in blood of buffaloes maintained in different space allowance conditions.

\begin{tabular}{lcccccc}
\hline \multicolumn{1}{c}{ Antioxidants } & \multicolumn{3}{c}{ Follicular fluid } & & Blood \\
& $\begin{array}{c}\text { Low density } \\
(\mathrm{n}=5)\end{array}$ & $\begin{array}{c}\text { High density } \\
(\mathrm{n}=5)\end{array}$ & P value & $\begin{array}{c}\text { Low density } \\
(\mathrm{n}=5)\end{array}$ & $\begin{array}{c}\text { High density } \\
(\mathrm{n}=5)\end{array}$ & P value \\
\hline Retinol $(\mu \mathrm{g} / \mathrm{ml})$ & $0.1 \pm 0.0$ & $0.2 \pm 0.0$ & 0.50 & $0.5 \pm 0.0$ & $0.4 \pm 0.1$ & 0.76 \\
$\alpha$-tocopherol $(\mu \mathrm{g} / \mathrm{ml})$ & $0.3 \pm 0.1$ & $0.3 \pm 0.1$ & 0.69 & $1.1 \pm 0.0$ & $1.1 \pm 0.3$ & 0.90 \\
$\begin{array}{l}\text { Ascorbate }(\mu \mathrm{m}) \\
\text { Protein-bound carbonyls } \\
\text { (nmoles/mgP) }\end{array}$ & $4.6 \pm 0.1$ & $4.3 \pm 0.0$ & 0.14 & $5.4 \pm 0.3$ & $5.2 \pm 0.4$ & 0.82 \\
$\begin{array}{l}\text { Nitrotyrosine } \\
\text { (nmoles/mgP) }\end{array}$ & $7.8 \pm 3.7$ & $7.6 \pm 3.0$ & 0.20 & $5.6 \pm 1.8$ & $12.0 \pm 2.6$ & 0.16 \\
\hline
\end{tabular}

\section{Lactation curve}

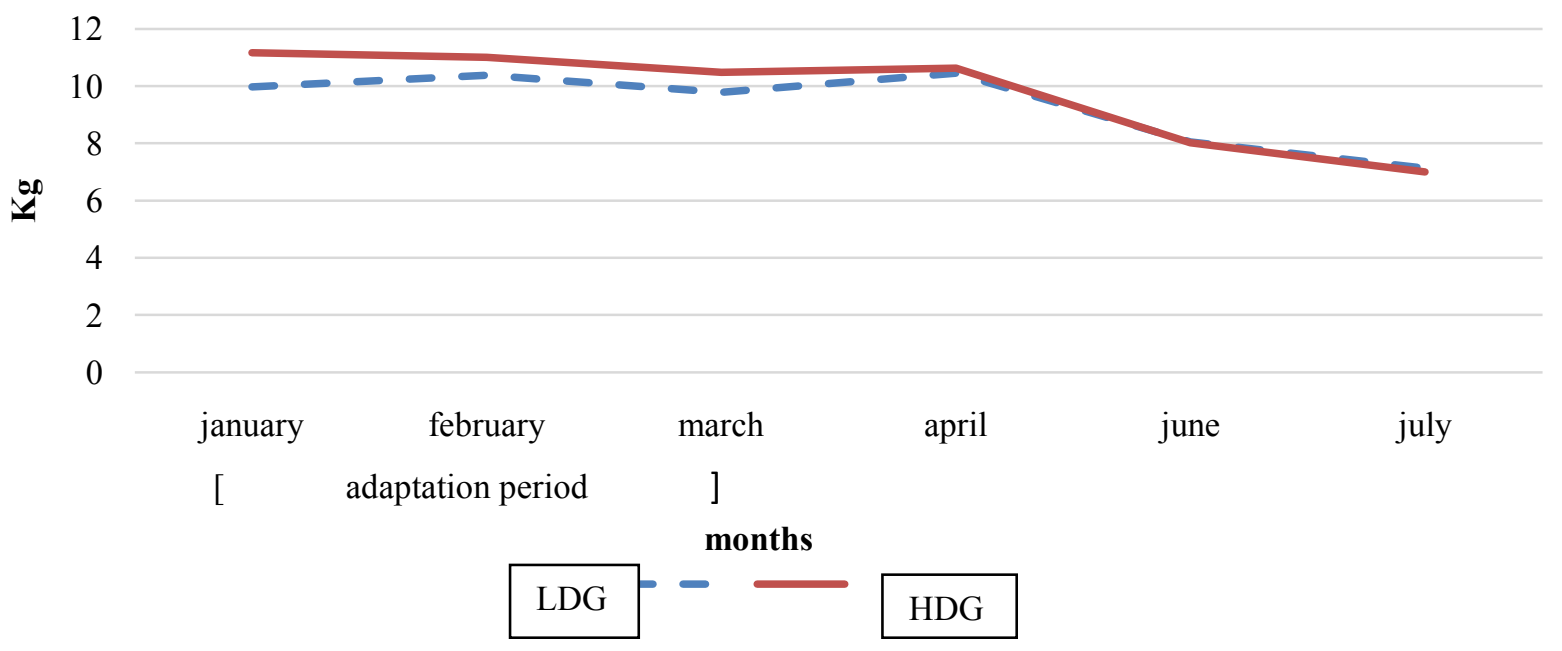

Figure 1. Lactation curve of the two groups (LDG and HDG) including the adaptation period between January and March.

\section{Discussion}

The results obtained in this study demonstrated that reproductive status (pregnant, not pregnant and LEM) and progesterone blood levels were not affected by the different space allowance conditions. On the contrary, P4 blood levels were significantly higher in pregnant buffaloes, compared to not pregnant and buffaloes underwent LEM, in agreement with other studies (Vecchio et al., 2012; Balestrieri et al., 2013). These findings support the hypothesis that LEM in buffalo is primarily due to a reduced $\mathrm{P} 4$ secretion by the 
corpus luteum. Adequate luteal function and threshold circulating concentrations of $\mathrm{P} 4$ in circulation are required to guarantee an uterine environment that promotes ongoing elongation of the embryo during the critical peri-implantation period of pregnancy (Balestrieri et al., 2013).

In our study no differences were found on blood metabolities and redox status between buffaloes maintained in high and low density. The metabolic status of buffaloes reared in different space allowance conditions was also evaluated in another study (Grasso et al., 2004), in which no differences were found. Although the study of oxidative stress is a relatively young field of research in ruminant breeding, understanding the role of oxidants and antioxidants in physiological and pathological conditions is highly studied. Buffaloes, as dairy cows, are exposed to various metabolic stressors (high milk yield, environmental conditions, etc.) and thus may increase oxidative stress levels. It has been proposed that the activation of antioxidant defenses is a preparative mechanism against oxidative stress caused by physiological stress situations (Hermes-Lima et al., 1988). Stress of any origin, including space allowance, handling and transport, is able to reduce body antioxidant resources in various species (Odore et al., 2011; Starvaggi Cucuzza et al., 2014). Moreover, in ruminants, oxidative stress has been associated with several pathological conditions, such as retained placenta, udder edema, and mastitis, which, in turn, may impair reproductive performances (Spears and Weiss, 2008). Therefore, antioxidant status can be considered indicative of reproductive function in dairy cattle and buffaloes.

Interestingly, no effects of ROS were also observed in the follicular fluid of the dominant follicle. Follicular fluid may be considered a biological 'window', reflecting metabolic and hormonal processes occurring in the microenvironment of the maturing oocyte before ovulation. Furthermore, it is also a predictor of outcome parameters such as fertilization, embryo cleavage and pregnancy rates in IVF (WienerMegnazi et al., 2004). This environment, in addition to granulosa cells, growth factors and steroids hormones, contains leukocytes, cytokines and macrophages, all of which can produce ROS (Attaran et al., 2000). In a study performed in buffalo species (Cassano et al., 1999), a higher level of ascorbate was recorded in follicular fluid rather than in plasma. This is not in agreement with our results, in which levels recorded in follicular fluid were lower than those in plasma. Several studies (Meur et al., 1999; Khan et al., 2011) showed lower concentration of ascorbic acid in large follicles, that possibly leads to weakening of the follicular basement membrane and hence to the follicle rupture at ovulation. Thus, our findings confirmed the lower ascorbate level is related to the size of the follicle. No difference in antioxidant analysis were found among groups suggesting us that buffalo's health and state of being were not influenced by the two different space allowance conditions.

Currently few data (Spagnuolo et al., 2007) are available on ROS and welfare in buffalo species. In our experiment ascorbate, $\alpha$-tocopherol, and retinol blood levels were similar between buffaloes maintained in high or low density. Therefore, it seems that space reduction, until $10 \mathrm{~m}^{2} /$ head does not adversely affect health and welfare, since these parameters are strictly correlated in host defense and immunological reactivity playing a role in resistance to infectious disease.

The effect of rearing conditions on serum cortisol concentrations has been investigated in bovine (Gupta et al., 2007; Odore et al., 2011) and also in weaned and adult buffaloes (Napolitano et al., 2004; Tripaldi et al., 2004). In our study a space of $10 \mathrm{~m}^{2} /$ head did not alter blood cortisol concentrations and cortisol levels in saliva and hair. It is worth pointing out the lack of differences in hair samples: these can be easily collected and preserved, do not stress the animals (Baliková, 2005) and their cortisol concentration reflects the cortisol synthesized in a long term period, avoiding changes due to circadian and ultradian rhythms (Kalra et al., 2007). Hence, buffaloes housed in different space conditions did not show any acute or chronic stress.

Finally, in contrast to previous reports (Zicarelli et al., 2005) no differences were also recorded in milk yield between the two groups. This can be considered a further confirm that $10 \mathrm{~m}^{2} /$ head can be used also without impairing productive efficiency.

In conclusion, this paper provides new information about the effect of space allowance on buffalo reproductive performances and welfare via biochemical, hormonal and haematological profile. As reported in cattle $10 \mathrm{~m}^{2} /$ head can be used without impairing reproductive efficiency and altering the metabolic status. Further studies are required to analyze differences between heifers and adult buffaloes also for longer period and under different climatic conditions.

\section{References}

Andrews AH, Poole A. 2004. Dairy farming. In: Andrews AH, Blowey RW, Boyd H, Eddy RG (Ed.). Bovine Medicine Diseases and Husbandry of Cattle. Oxford, UK: Blackwell Science Ltd. pp. 22-52.

Attaran M, Pasqualotto E, Falcone T, Goldberg JM, Miller KF, Agarwal A and Sharma RK. 2000. The effect of follicular fluid reactive oxygen species on the outcome of in vitro fertilization. Int $J$ Fertil Womens Med, 45:314-320.

Balestrieri ML, Gasparrini B, Neglia G, Vecchio D, Strazzullo M, Giovane A, Servillo L, Zicarelli L, D'Occhio MJ, Campanile G. 2013. Proteomic profiles of the embryonic chorioamnion and uterine caruncles in buffaloes (Bubalus bubalis) with normal and retarded embryonic development. Biol Reprod, 88:119, 14 pp.

Baliková M. 2005. Hair analysis for drugs of abuse. Plausibility of interpretation. Biomed Pap Med Fac Univ Palacky Olomouc Czech Repub, 149:199-207.

Beal MF. 2002. Oxidatively modified proteins in aging and disease. Free Radic Biol Med, 32:797-803.

Berlett BS, Stadtman ER. 1997. Protein oxidation in aging, disease, and oxidative stress. J Biol Chem, 
272:20313-20316.

Buss H, Chan TP, Sluis KB, Domigan NM, Winterbourne CC.1997. Protein carbonyl measurement by a sensitive ELISA method. Free Radic Biol Med, 23:361-366.

Cassano E, Tosto L, Balestrieri M, Zicarelli L, Abrescia P. 1999. Antioxidant defense in the follicular fluid of water buffalo. Cell Physiol Biochem, 9:106-116. Dalle-Donne I, Rossi R, Giustarini D, Milzani A, Colombo R. 2003. Protein carbonyl groups as biomarkers of oxidative stress. Clin Chim Acta, 329:2338.

De Rosa G, Napolitano F, Saltalamacchia F, Bilancione A, Sabia E, Grasso F, Bordi A. 2007. The effect of rearing system on behavioural and immune responses of buffalo heifers. Ital J Anim Sci, 2:12601263.

De Rosa G, Grasso F, Brughieri A, Bilancione A, Di Francia A, Napolitano F. 2009. Behavior and milk production of buffalo cows as affected by housing system. J Dairy Sci, 92:907-912.

Di Palo R, Midea D, Campanile G, Rossi N, Zicarelli L. 2001.Influence of management system on reproductive activity of dairy buffaloes during the hot season. In: Proceedings of the 6th World Buffalo Congress, 2001, Maracaibo, Venezuela. Maracaibo WBC. pp. 130-136.

Doyle D. 2006. William Hewson (1739-74). The father of haematology. Br J Haematol, 133:375-381.

Ferranti C, Quadri FD, Palleschi L, Marchiafava C, Pezzolato M, Bozzetta E, Caramelli M, Draisci R 2011. Studies on the presence of natural and synthetic corticosteroids in bovine urine. Steroids, 76:616-625.

Garner JP, Kiess AS, Mench JA, Newberry RC, Hester PY. 2012.The effect of cage and house design on egg production and egg weight of White Leghorn hens: an epidemiological study. Poult Sci, 91:1522-1535.

Grasso F, Terzano GM, De Rosa G, Tripaldi C, Napolitano F. 2004. Influence of housing conditions and calving distance on blood metabolites in water buffalo cows. Ital J Anim Sci, 3:275-282.

Gupta S, Earley B, Crowe MA. 2007. Pituitary, adrenal, immune and performance responses of mature Holstein $x$ Friesian bulls housed on slatted floors at various space allowances. Vet $J, 173: 594-604$.

Halliwell B, Gutteridge J. 1999. Free Radicals in Biology and Medicine. 3rd ed. Oxford, UK: Clarendon Press.

Hemsworth PH, Rice M, Nash J, Giri K, Butler KL, Tilbrook AJ, Morrison RS. 2013. Effects of group size and floor space allowance on grouped sows: aggression, stress, skin injuries, and reproductive performance. $J$ Anim Sci, 91:4953-4964.

Hermes-Lima M, Storey JM, Storey KB. 1988. Antioxidants defenses and metabolic depression. The hypothesis of preparation for oxidative stress in land snails. Comp Biochem Physiol B Biochem Mol Biol, 120:437-448.

Johnston LJ, Li YZ. 2013. Performance and wellbeing of sows housed in pens retrofitted from gestation stalls. J Anim Sci, 91:5937-5945.
Khan FA, Das GK. 2011. Follicular fluid nitric oxide and ascorbic acid concentrations in relation to follicle size, functional status and stage of estrous cycle in buffalo. Anim Reprod Sci, 125:62-68.

Kalra S, Einarson A, KaraskovT,Van Uum S, Koren G. 2007. The relationship between stress and hair cortisol in healthy pregnant women. Clin Invest Med, 30:103-107.

Meur SK, Sanwal PC, Yadav MC. 1999. Ascorbic acid in buffalo ovary in relation to oestrous cycle. Indian J Biochem Biophys, 36:134-135.

Mormède P, Andanson S, Aupérin B, Beerda B, Guémené D, Malmkvist J, Manteca X, Manteuffel G, Prunet $P$, van Reenen CG, Richard S, Veissier I. 2007. Exploration of the hypothalamic-pituitary-adrenal function as a tool to evaluate animal welfare. Physiol Behav, 92:317-339.

Möstl E, Maggs JL, Schrötter G, Besenfelder U, Palme R. 2002. Measurement of cortisol metabolites in faeces of ruminants. Vet Res Commun, 26:127-139

Napolitano F, De Rosa G, Grasso F, Bordi A. 2004 Influence of space restriction on welfare of weaned buffalo calves (Bubalus bubalis). Livest Prod Sci, 86:117-124.

Neglia G, Gasparrini B, Caracciolo di Brienza V, Di Palo R, Campanile G, Presicce GA, Zicarelli L. 2003a. Bovine and buffalo in vitro embryo production using oocytes derived from abattoir ovaries or collected by transvaginal follicle aspiration. Theriogenology, 59:1123-1130.

Neglia G, Gasparrini B, Di Palo R, De Rosa C, Zicarelli L, Campanile G. 2003b. Comparison of pregnancy rates with two estrus synchronization protocols in Italian Mediterranean buffalo cows. Theriogenology, 60:125-133.

Neglia G, Natale A, Esposito G, Salzillo F, Adinolfi L, Campanile G, Francillo M, Zicarelli L. 2008. Effect of prostaglandin F2 $\alpha$ at the time of A.I. on progesterone levels and pregnancy rate in synchronized Italian Mediterranean buffaloes. Theriogenology, 69:953-960

Negrão JA, Porcionato MA, Passille AMD, Rushen J. 2004. Cortisol in saliva and plasma of cattle after ACTH administration and milking. $J$ Dairy $S c i$, 87:1713-1718

Niswender GD. 1973. Influence of the site of conjugation on the specificity of antibodies to progesterone. Steroids, 22:413-424.

Odore R, Badino P, Re G, Barbero R, Cuniberti B, D'Angelo A, Girardi C, Fraccaro E, Tarantola $M$. 2011. Effects of housing and short-term transportation on hormone and lymphocyte receptor concentrations in beef cattle. Res Vet Sci, 90:341-345.

Ohashi OM. 1994. Estrous detection in buffalo cow. Buffalo J, 2:61-64.

Pursley JR, Mee MO, Wiltbank MC.1995.Synchronization of ovulation in dairy cows using PGF2alpha and GnRH. Theriogenology,44:915923.

Rossi P, Vecchio D, Neglia G, Di Palo R, Gasparrini B, D'Occhio MJ, Campanile G. 2014. Seasonal fluctuations in the response of Italian Mediterranean 
buffaloes to synchronization of ovulation and timed artificial insemination. Theriogenology, 82:132-137.

Skaggs CL, Able BV, Stevenson JS.1986. Pulsatile or continuous infusion of luteinizing hormone-releasing hormone and hormonal concentrations in prepubertal beef heifers. J Anim Sci, 62:1034-1048.

Spagnuolo MS, Cigliano L, Balestrieri M, Porta A, Abrescia P. 2001. Synthesis of ascorbate and urate in the ovary of Water Buffalo. Free Radic Res, 35:233243.

Spagnuolo MS, Cigliano L, Sarubbi F, Polimeno F, Ferrara L, Bertoni G, Abrescia P. 2003.The accumulation of alpha-tocopherol and retinol in the milk of water buffalo is correlated with the plasma levels of triiodothyronine. Biofactors, 19:197-209.

Spagnuolo MS, Vecchio D, De Rosa R, Polimeno F, Balestrieri A, Zicarelli G, Ferrara L, Campanile G. 2007. Effect of different housing conditions on several indices of blood redox status and on reproductive performance in buffalo cows. Ital J Anim Sci, 6:697700 .

Spagnuolo MS, Sarubbi F, Rossetti C, Grazioli G, Di Meo GP, Iannuzzi L. 2011. Effect of dioxin exposure on several indices of blood redox status in lactating buffalo cows. J Dairy Res, 78:154-159.

Spears JW, Weiss WP. 2008. Role of antioxidants and trace elements in health and immunity of transition dairy cows. Vet $J$, 176:70-76.

Starvaggi Cucuzza L, Riondato F, Macchi E, Bellino C, Franco G, Biolatti B, Cannizzo FT. 2014. Haematological and physiological responses of Piemontese beef cattle to different housing conditions Res Vet Sci, 97:464-469.
Tripaldi C, De Rosa G, Grasso F, Terzano GM, Napolitano F. 2004.Housing system and welfare of buffalo (Bubalus bubalis) cows. Anim Sci, 78:477-483.

Turner AI, Hemsworth PH, Tilbrook AJ. 2005. Susceptibility of reproduction in female pigs to impairment by stress or elevation of cortisol. Domest Anim Endocrinol, 29:398-410.

Vecchio D, Neglia G, Gasparrini B, Russo M, Pacelli C, Prandi A, D'Occhio MJ, Campanile G. 2012.Corpus luteum development and function and relationship to pregnancy during the breeding season in the Mediterranean buffalo. Theriogenology, 77:18111815.

Wiener-Megnazi Z, Vardi L, Lissak A, Shnizer S, Reznick AZ, Ishai D, Lahav-Baratz S, Shiloh H, Koifman M, Dirnfeld M. 2004.Oxidative stress indices in follicular fluid as measured by the thermos chemiluminescence assay correlate with outcome parameters in in vitro fertilization. Fertil Steril, 82:1171-1176.

Zicarelli L, Esposito L, Campanile G, Di Palo R, Armstrong DT. 1997.Effects of using vasectomized bulls in artificial insemination practice on the reproductive efficiency of Italian buffalo cows. Anim Reprod Sci, 47:171-180.

Zicarelli F, Campanile G, Gasparrini B, Di Palo R, Zicarelli L. 2005. Influence of the period and of the space on the milk production and on the consumption of dry matter in the Italian Mediterranean Buffalo. In: Proceedingsof the 3rd Congresso Nazionale sull' Allevamento del Bufalo; 1st Buffalo Symposium Europe and the Americas, Paestum, SA, Italy. Paestum, SA, Italy: CNAB. pp. 75-76. 